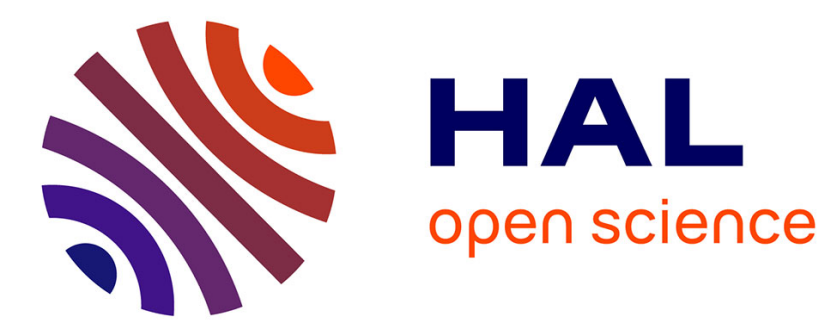

\title{
Referential markers in Oceanic nominalized constructions
}

Claire Moyse-Faurie

\section{To cite this version:}

Claire Moyse-Faurie. Referential markers in Oceanic nominalized constructions. Finiteness and Nominalization, pp.171 - 204, 2016, 10.1075/tsl.113.08moy . halshs-01477324

\section{HAL Id: halshs-01477324 \\ https://shs.hal.science/halshs-01477324}

Submitted on 2 Mar 2017

HAL is a multi-disciplinary open access archive for the deposit and dissemination of scientific research documents, whether they are published or not. The documents may come from teaching and research institutions in France or abroad, or from public or private research centers.
L'archive ouverte pluridisciplinaire HAL, est destinée au dépôt et à la diffusion de documents scientifiques de niveau recherche, publiés ou non, émanant des établissements d'enseignement et de recherche français ou étrangers, des laboratoires publics ou privés. 


\title{
Referential markers in Oceanic nominalized constructions
}

\author{
Claire Moyse-Faurie (UMR 7107 LACITO-CNRS)
}

\section{Introduction 1}

This article is about compatibilities and restrictions within Oceanic nominalized constructions. Regardless of whether a nominalizing affix is required or whether the nominal context is sufficient in itself to license a verb in a noun phrase position, Oceanic languages exhibit various restrictions on the occurrence of specific markers (tense-aspect-mood, negation markers, articles, possessive markers) in phrasal/clausal nominalizations. More often than not, action nominalization (i.e. propositional/activity/state nominalization) goes together with non-finiteness in the verbal domain, as well as with co-occurrence restrictions in the nominal domain (e. g. in the choice of articles). In most languages, however, nominalized clauses partake of both nominal and verbal properties. It is indeed these mixed features, and the variations observed across languages, that make them very interesting to study. Nominalization and deverbalization processes are said to be correlated with hierarchical constraints, and in the last part of this article I will try address the question whether the principles put forward in the literature are justified by the Oceanic data ${ }^{2}$. Before I turn to my main topic, however, it is necessary to make some general introductory remarks concerning the main predicative and categorial properties found in most of the languages taken into account in this article.

Predicates in Kanak as well as in Polynesian language are not marked for tense or person. These categories are expressed in the verbal clause by independent morphemes. In verbal phrases, predicates are accompanied by various particles, either preposed or postposed. Among the preverbal particles we find pronominal subjects indicating person, number and clusivity of the subject, tense/aspect markers and negation. The postverbal particles are directionals and, in some languages, other tense/aspect markers.

There are, however, a few exceptions to the predicate invariability: (i) In a few cases Polynesian predicates are marked for number and this number inflection is kept in nominalized clauses (§5). (ii) Some predicates in Kanak languages are inflected depending on the object (object incorporation, or pronominal vs. definite nominal object). Moreover, we find different transitive or applicative suffixes in most Oceanic languages, which may also be kept in nominalized clauses.

A further introductory remark concerns the small inventory of overt categories in Oceanic languages. Languages of this family differ in the obligatory presence or absence of expressions of tense, person or illocutionary force. For the time being I will just illustrate this variation by mentioning some striking differences between two related languages:

- In Xârâcùù (Mainland of New Caledonia), there is no obligatory expression for tense or for person in impersonal constructions, but a subject is most often expressed, either as pronoun or as a lexical item. The modern constituent order is SVO, but the ancient order sVO smS is still used in some contexts such as topicalization ("afterthought"), and in this case, a pronominal clitic (s) is obligatorily expressed before the predicate, co-referring with the postposed subject (S), which, in turn, is introduced by the subject marker (sm).

\footnotetext{
1 I would like to thank an anonymous reviewer, and Ekkehard König, for critical comments and stylistic improvements.

2 My own data mostly concern several Kanak (New Caledonia: Xârâcùù and Xârâgurè) and Polynesian (East Futunan and East Uvean) languages, on which I have done intensive fieldwork.
} 
- In East Futunan (Wallis and Futuna), no argument is obligatorily expressed, but verbal clauses are always marked for tense or aspect.

The following text is structured as follows: First of all (Chapter 2), a distinction is drawn between three types of nominalizations, depending on whether an article identifies a nominalization (type 1), whether a preverbal affix signals this categorial status (type 2) or whether both co-occur (type 3). An additional characterization of nominalizations in Oceanic languages is then provided by describing their distribution in terms of syntactic positions and partly also in terms of functions. Chapter 3 provides evidence for the claim that contrary to widespread views tense markers and aspect markers do occur in many Oceanic languages. It will also be shown, however, that there are constraints for individual tense-aspect markers in individual languages depending on a variety of factors. Analogous variation is also found as far as the occurrence of negative markers (Chapter 4) and the marking of grammatical relations (ergative vs. accusative type) are concerned (Chapter 7). Agreement and the occurrence of adverbs do not seem to give rise to restrictions (Chapter 5 and 6). In the final conclusions (Chapter 8), diachronic considerations and typological generalizations will be discussed.

\section{Nominalization : markers and functions}

\subsection{Three types of nominalizations}

In most Oceanic languages, there are no restrictions on the predicate function accessibility: any lexical morpheme may be used as predicate and thus combine with tense, aspect and person markers. Lexical items referring to entities, however, only occur in intransitive constructions (1), (2a), and have to be combined with derivational affixes in order to occur in transitive constructions (2b):

Xârâcùù (Mainland of New Caledonia)

1. Kwémwaa nää apuu-döö, kwé mê nê-kwââ.

Kwémwaa PROG.PST master-earth water and leaf-tree

'Kwémwaa was the master of the earth, of water and of the leaves.'

East Futunan

2a. E puloga a au i aso fuli.

NPST hat ABS 1SG OBL day all

'I wear a hat every day.' (Lit. I hat every day)

2b. E puloga-'i e au le puloga o loku tupuna.

NPST hat-TR ERG 1SG ART hat POSS my grandfather

'I am wearing my grandfather's hat.'

Lexical items referring to states or actions can only occur in a non-predicative function if they are nominalized. There are three types of "action nominalization" (Comrie and Thompson 2007: 335) in Kanak and Polynesian languages: In the first type nominalizing affixes are used, whereas in second the presence of a specific/definite article is sufficient for the phrasal or clausal nominalizing process (Moyse-Faurie 2007). The presence of possessive expressions is also a clear indicator of a nominalization. The coocurrence of both kinds of markers identifies a third type. In all three cases, however, the nominalized forms may retain certain properties of the verbs they are related to, including tense-aspect markers, directionals, verbal modifiers and agent markers, as we will see below. 
The first type (a): In languages with articles (as for example, some of the languages of the Loyalty Islands, Fijian, Western Polynesian languages), an article nominalizes a verb or a verb phrase, a case often also described as zero nominalization. It is the article which bears the referential index, as is now generally assumed in syntactic theory. This is the case in Boumaa Fijian, where Dixon (1988:130-131) points out the obligatory presence of the common article $a / n a$ introducing the nominalized clause, which also includes a possessive pronoun, corresponding to the intransitive subject/agent of the verbal clause:

Boumaa Fijian (Dixon 1988:130-131)

3. Au maarau va'alevu i na omudou yaco mai qoo.
1sG happy greatly at ART your
'I'm very happy at your arrival here.'

In these languages, nominalizing affixes do exist, but their main function is to derive new lexemes such as concrete deverbal nouns, and they are not used to nominalize an entire clause. The choice of the article used to nominalize a clause or a phrase is often not free. In most Polynesian languages, only the specific article may nominalize a verb phrase, as is the case with le in East Futunan (PPN *te : Tongan e/he; Samoan le; Tokelau, Tahitian te): East Futunan (Moyse-Faurie 1997:95)

4a. Kua tā le lali e Tuilekete $i$ le usu. PFV hit SPEC bell ERG Tuilekete OBL SPEC morning 'Tuilekete hit the bell in the morning.'

4b. Ko lenā loa le tāo le lalie Tuilekete la i le usu. PRED DEIC then SPEC hit POSS SPEC bell ERG Tuilekete EMPH OBL SPEC morning 'Then comes Tuilekete hitting the wooden bell in the morning.' (Lit. this is then the hitting of the bell by Tuilekete in the morning)

The specific article used to nominalize a verbal clause has been analyzed by Vernaudon and Rigo (2004) as a 'translatif' (in Tesnière's (1959: 80) terminology). In some languages, the non-specific articles may nominalize verb phrases, but the nominalized phrase then loses its reference to an event; it behaves as a type of entity, and cannot be determined by any aspect marker or by a directional or other adverb, as we will see below in §3.2.3.

The second type (b): In Kanak languages of the Mainland, it is the presence of a nominalizing prefix on the verb which marks the nominalization of the verb phrase or of the entire clause. This is shown by the example (5b) from Xârâcùù, contrasting in this point with the verbal clause (5a):

Xârâcùù (Mainland of New Caledonia) (Moyse-Faurie 1995:57)

5a. Nèpôrô mê Tuura mê na.

Nèpôrô and Tuura come PST

'The Nèpôrô clan and the Tuura clan have come.'

5b. Kèè-mê na rè nyärä Nèpôrô mê Tuura.

NMLZ-come PST POSS 3PL Nèpôrô and Tuura

'The Nèpôrô clan and the Tuura clan have come.' (Lit. their [past] arrival, the Nèpôrô and the Tuura)

In Xârâcùù (Moyse-Faurie 1995:183-190), as in all Kanak languages, there are several nominalizing prefixes, such as: kèè - 'way, manner', ù - 'place', a- 'action', xwâ- 'result', xêepossibility. 
The third type (c): Both the article and a nominalizing prefix occur, as in Cèmuhî, where the presence of both the article $a$ and the action nominalizing prefix $a$-in (6a) contrasts with their absence in the verbal clause (6b):

Cèmuhî (Mainland of New Caledonia) (Rivierre 1980:267)

$\begin{array}{llll}\text { 6a. } \quad \boldsymbol{a} \quad \boldsymbol{a} \text {-taa-bé } & \text { tè-lé } & \text { 6b. } & \text { Lé taa-bé. } \\ \text { ART NMLZ-go.up-DIR } & \text { POSs-3PL } & \text { 3PL go.up-DIR } \\ \text { 'their going up here' } & \text { 'They are going up here.' }\end{array}$

An additional characterization of nominalizations in Oceanic languages can be provided by describing their possible syntactic positions within a more complex sentence or their functions as sentence types when they are used as independent sentential units.

\subsection{Range of functions}

It is well-known that nominalized clauses are very frequent in Oceanic languages, in traditional stories as well as in spontaneous talk. Clark (1981:72-78) lists some of the main contexts and functions associated with nominalizations in Polynesian languages, which can also be identified in other Oceanic languages.

Nominalized clauses may be used in all of the following functions: (i) as nominal clauses without any predicative marker ("stand-alone" or "non-embedded nominalization"); (ii) as relative clauses; (iii) as noun phrases occurring as arguments or possessive adjuncts; (iv) as causal adjuncts; (v) in clausal complementation; (vi) in imperative clauses; (vii) in exclamative clauses, which are indeed very often expressed through nominalization (MoyseFaurie 2011), and which may also include tense-aspect markers.

In two of these cases, (i) and (vii), nominalizations are used as completely independent utterances, in the others a sentence is rank-shifted to the status of a clausal constituent. These uses will now be discussed in more detail.

(i) Nominal clauses: Nominalizations are found as the predicates of nominal clauses, i.e. without any predicative marker, as in the independent clause Xârâcùù (7) and the equative ones in (8) and (9), or in clauses introduced by the predicative marker ko, as in East Uvean (10). Most of the following examples include a temporal specification, and are thus anchored in time.

Xârâcùù (Moyse-Faurie 1995:57)

7. Kèè-söömè na rè panèè-rè niè. NMLZ-kill PST POSS father-POSS.3SG he(INDEP)

'His father killed him.' (Lit. the murder of his father, he)

8. Ù-kaxê röö, kèè-da-xëtë röö.

NMLZ-big POSS+2SG NMLZ-eat-hard POSS+2SG

'Your size is due to your greediness'.

9. X Xwâ-sô rè pwâ-mêdè ngê xwâda $a$, kèè-fädë na rè xwâchêe... NMLZ-fall pOss fruit-orange.tree during year DEIC NMLZ-walk PST POSS butterfly

'The fall of the mandarines from the tree this year is due to the arrival of butterflies...'

\section{East Uvean}

10. Ko te mole kei tō o te kava e ia. PRED SPEC NEG PROG plant POSS SPEC kava ERG 3SG

'(It is a fact) he doesn't grow kava anymore.' 


\section{(ii) Relative clauses}

In the range of uses of nominalizations that are encountered in the world languages, the attributive function of relative clauses is well attested in Oceanic languages. The relative clauses from Xârâcùù in (11) and (12) are nominalized clauses, lit. 'the big wave [which is] the pushing result of the Uvean chief' in (11), whereas in the Tahitian example (13), it is an identificational clause, introduced by the predicative marker 'o, qualifying its antecedent Teri'i.

Xârâcùù (Moyse-Faurie 1995:218)

11. Kasööjii citââ nä rè jii mwîn kwétaa êê-sùù rè aaxa Pokwé. Sucker-Bird stand up and 3sG suck up big wave NMLZ-push POss chief Uvea 'Sucker-Bird stands up and sucks up the big wave pushed by the chief of Uvea.' (lit. 'the big wave [which is] the pushing result of the Uvean chief)

12
Xûûchî wâ tecâ cè kètè pôô ù-sugwétuu rè pabéé-rè.

child PFV go.towards for place hole NMLZ-stick POSS COLL.brother-POSs3sG

'The child went toward the hole where his brothers were stuck.'

Tahitian (Lazard \& Peltzer 2000:83)

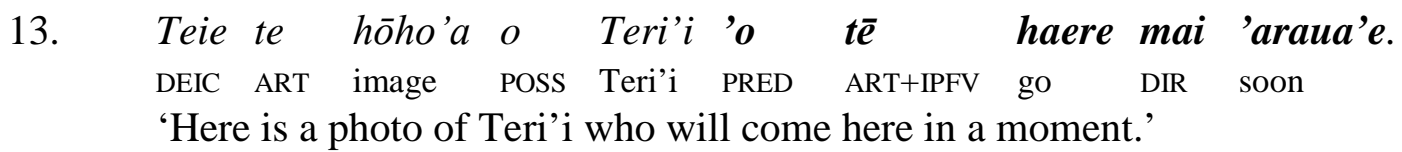

(iii) Arguments: Unsurprisingly, nominalizations may occur in verbal clauses, as subjects in Xârâcùù (14) and as objects in Tahitian (15):

Xârâcùù (Moyse-Faurie 1995:190)

14. Xêê-da rè nâa xwi, pââ-nâ wâ siè paii.

NMLZ-eat POSS 1SG exist tooth-1SG PFV NEG ill

'I can eat, my teeth are not hurting anymore.' (Lit. my possibility of eating exists...)

Tahitian (Vernaudon et Rigo 2004:467)

15. Nāhea te tatara $i$ te reira mau fifi?

how SPEC resolve OBJ SPEC ANAPH PL problem

'How to resolve these problems?'

(iv) Causal adjuncts: Nominalizations are also found as causal adjuncts.

Xârâcùù

16. E $\quad$ xwêê na xwirè kèè-pûxûrû.

3sG fall PST because NMLZ-run

'He fell because he was running.'

East Futunan (Moyse-Faurie 1997:117)

17. Kua fifigo lua le toe i le fia inu. PFV dry very SPEC child OBL SPEC DESID drink

'The child got very thirsty.' (Lit. the child became very dry in the wanting to drink)

(v) Completives: Nominalizations can occur as clausal complements.

Xârâcùù 
18. Kwiè xwi cè kè̀̀-xwa.

rain make for NMLZ-fall

'It is going to rain soon.' (Lit. rain is preparing for falling)

19

$\begin{array}{lllll}\text { Nâ nââbu môrô na } & \text { kèè-sa rè } & \text { bwè. } & \\ \text { 1SG begin already } & \text { PST } & \text { NMLZ -catch } & \text { POSS } & \text { crab } \\ \text { 'I had already begun to fish for crabs.' } & & \end{array}$

(vi) Imperative clauses: They are also frequent in imperative clauses, as clausal arguments. Xârâcùù

20. Cokwa kèè-sa rè xötö mûduè-rö!

finish NMLZ-hit POSS male young.sibling-POSS2SG

'Stop beating your brother!'

21. Xwata kèè-sööté rè apaa tö nuö!

listen NMLZ-make.noise poss Dad in forest

'Listen to the noise Dad is making in the forest!'

On the other hand, there seem to be specific constraints on nominalizations in this use. In East Uvean, for example, only temporal adverbs, rather than adverbs of other semantic types (such as fa' $a$ 'often' in the East Uvean example below) seem to be possible in such nominalized imperative clauses to express aspect/tense specifications:

East Uvean

22. 'Aua te fa'a lau mai o te me'a nei!

PROH SPÉC often say DIR POSS SPEC thing this

Don’t always tell me this thing!

(vii) Exclamative clauses: Finally, nominalizations are used as exclamatives, either as part of larger constructions or as independent utterances.

Even though some exclamative constructions are subordinate structures (cf. below examples (29) to (31) of type 3), most of them exhibit specific features, at least in Oceanic languages, which have nothing to do with declaratives or interrogatives, as is typically the case in European languages, but clearly typical properties of nominalization. The use of nominalizations in what is now often called a stance function (Yap and Matthews 2008; Noonan 1997:381), i. e. to signal the speaker's perspective or attitude toward the state of affairs expressed in the clause, has recently been described by Lichtenberk (2011) for Toqabaqita:

Toqabaqita (Solomon islands) (Lichtenberk, 2011:715)

23. Qaa! Ngata-laa sula doo qoro qeri!

'Hey! All this talking about the things.' (Lit. Hey! Talking about those many things)

Different types of exclamative nominal clauses are attested in Oceanic languages, depending on whether the nominalization is part of a larger construction (type 2 and 3) or not (type 1) (see Moyse-Faurie 2011 for more details). The first type is a 'stand-alone' nominal clause, i.e. without any copular or predicative marker. This type may include a nominalizing affix on its head-noun as in the Toqabaqita example (23), or it may occur without any nominalizing affix, as in Tokelauan (24).

Tokelauan (Hooper 1996:233) 
24. Kai te kehe o tau lalaga!

INTERJ SPEC different POSS your weave

'What a peculiar way of weaving you have!'

The head-noun of such bare exclamative clauses may be an overtly derived-noun as in

Tuvaluan (25):

Tuvaluan (Besnier 2000:40)

25. Te galii-ga o te mei maafai $e$ falai!

SPEC good-NMLZ POSS SPEC breadfruit when NPAST fry

'Breadfruit is so good when fried!'

(Lit. the goodness of the breadfruit when [one] has fried [it]

Similar cases can be found in Xârâcùù (26) and in Cèmuhî (27), where exclamative clauses may also consist of a nominalized verb + a possessive adjunct, most often expressing surprise or admiration.

Xârâcùù

26. Kèè-téé na rèè!

NMLZ-look at PST POSS+3sG

'How he was looking!' (Lit. his way of having looked at!)

Cèmuhî (Mainland of New Caledonia) (Pascale Poiba, p.c.)

27. A bwö-bwöli è-ng!

ART NMLZ-late POSs-3sG

'[It’s incredible] how late he arrives!'

The second type of exclamative nominalized clauses is the 'copular-type' nominal clause, i.e. a nominal clause introduced by a predicative marker.

East Futunan (Moyse-Faurie 1997:20)

28. E fia ano ki Lokā ka ko le mama'o fua!

NPAST DESID go OBL Loka but PRED SPEC far INT

'I would like to go to Loka, but it is so far!'

The third type of nominal exclamatives consists of a prepositional phrase with a nominalized head-noun, i.e. a type of subordinate structure. Prepositional exclamative clauses are introduced in East Futunan by the dynamic centrifugal locative preposition ki (PPn *ki) and by the static one (i) in East Uvean.

East Futunan (Moyse-Faurie 1997:181)

29. Ki le fia sā o Paulo 'aia!

OBL SPEC DESID show POSS Paulo DEIC

'How Paulo is boasting!'

East Uvean

30. I matakovi te puaká!

OBL ugly SPEC pig

'How ugly this pig is!'

In (30), the argument is just placed after the stative verb, but in (31), it is expressed as a possessor, maybe because of the presence of an adverb.

East Uvean

31. I ma'uli lelei o te fusi nei!

OBL life well POSS SPEC banana-tree DEIC

'How well these banana trees are growing!' Lit. at the good life of these banana trees) 


\section{Tense aspect markers in nominalized clauses}

\subsection{Occurrence of tense aspect markers}

Tense-aspect markers are rarely found in nominalized clauses across languages. In fact, it is often said that they are impossible in specific Polynesian languages, as is shown §2.1, starting with Chung (1974:642), who already asserted: "In many PN languages, sentence nominalizations are derived by replacing the tense marker of a sentence with an article and adding a suffix to the verb." [my emphasis]

An even more general claim can be found in Naess and Hovdhaugen (2011): "The main feature of decategorization of Vaeakau-Taumako nominalized clauses is the loss of the tenseaspect-mood marker. This is accompanied by a recategorization feature, the introduction of an article or possessive pronoun to replace the tense-aspect mood marker. Other verbal properties are retained to varying degrees. A nominalized transitive clause retains its object argument, encoded in the same manner as in a verbal clause” (2011:192).

A similar observation is made by Mosel \& Hovdhaugen (1992:531) for Samoan:

"Nominalized verbal clauses... can be marked for case by prepositions and are determined by articles, but lack TAM particles”.

Niko Besnier (2000:510) made analogous observations for Tuvaluan: "Nominalized verbs come in two types [...]: a 'bare' form, which is identical to that of the finite form of the verb; and a suffixed form, which is derived by attaching the nominalizing suffix -Vga to the verb. In both cases, the verb loses its tense-aspect-mood markers". In other words, nominalized clauses cannot occur with tense-aspect-mood markers (32a), whereas the corresponding subordinate clauses (32b) do:

Tuvaluan (Besnier, 2000:62)

32a. Koo oti te solooga o temotou fekei.

PFV finish SPEC grate+NMLZ POSS 1PL.EXCL pudding

'We're done grating the swamp taro [for making] pudding.' (Lit. is finished the grating of our swamp taro for pudding)

32b. Koo oti ne solo temotou fekei.

PFV finish PST grate 1PL.EXCL pudding

id. (Lit. is finished has been grated our swamp taro for pudding)

And, to give two more examples of pertinent observations on Polynesian languages, Bauer makes the following statement for Maori [my emphasis] "In the nominalization, there is no TAM marker, and the verb base has as a suffix the appropriate form of Canga." (Bauer 1997:517). In Tahitian, according to Lazard and Peltzer (2000: §12.4.1), the suffix -ra'a is normally associated with the nominalization of verbal clauses, the article te replacing the tense-aspect marker. Assertions of this kind are also often made for other Oceanic, nonPolynesian languages. According to Frank Lichtenberk (2011): "the tense distinction and negation are expressed by means of preverbal subject markers, but these do not occur with nominalizations” (Lichtenberk 2011:706). Analogous observations have been put forward for Lolovoli by Hyslop (2001:391): "Nominalised complements convey the same meaning as complement clauses, but they are non-finite”.

In view of what is generally found cross-linguistically such observations are not surprising. In many languages, very few verbal features such as tense-aspect markers are retained in nominalizations. But what is it that prevents the occurrence of tense-aspect markers in nominalized constructions? Arguments do retain some of their verbal marking, and directionals or other adverbs are very often part of nominalized clauses. So, why are tenseaspect markers not kept, too? The preceding observations do not provide an explanation for the observed asymmetry between nominal and verbal constructions. If nominalizations refer 
to events, then these events can certainly be located in time as the following clumsy cases from English show: John's former/future writing of books. The frequently observed restrictions can therefore not be semantic ones.

And indeed it turns out that tense-aspect markers do occur in nominalized constructions, at least in some Oceanic languages. On the other hand, this compatibility can only be found in some languages of the same subgroup, while other languages do not manifest it and this distribution of variants poses similar problems for an explanation as the above observation on the total lack of tense marking in nominalizations in specific languages has done. Is this a recent evolution, a way of increasing the parallelism between noun phrase and verb phrase? It would be interesting to understand why there is such a need for more finiteness and thus temporal reference in the nominalizations than is required in most languages.

The compatibility of aspect and/or tense markers with nominalization is attested at least in some Polynesian languages, in Fijian and in several New Caledonian languages. We will now present examples of these tense-aspect categories in nominalized clauses, before turning to the constraints that may be found.

\section{a) Past tense}

In Xârâcùù, most of the tense-aspect markers, whatever their position in the verb phrase is, may occur in nominalized constructions, as well. The following examples illustrate various syntactic contexts where this possible: Past tense is expressed, in (33), after the intransitive verb, in an independent nominalized sentence, in a nominalized relative clause (34), as well as in an dislocated argument position of a nominalized phrase (35):

Xârâcùù

33. Kèè-mê na rè nyärä Nèpôrô mê Tuura.

NMLZ-come PST POSS 3PL Nèpôrô and Tuura

'The Nèpôrô clan and the Tuura clan have come.' (lit. their [past] arrival, the Nèpôrô and the Tuura)

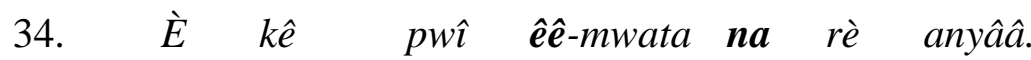

3SG eat.tubers banana NMLZ-grate PST POSS mummy

'He is eating bananas which have been chopped up by his mother.'

35. Xêê-da na rè nâ nää xwi, pââ-nâ wâ nää sii paii.

NMLZ-eat PST POSS 1SG PROG.PST exist tooth-1SG PFV PROG.PST NEG sick

'I was able to eat, my teeth were not hurting anymore.'

The past tense is also found in nominalizations in Fijian:

Fijian (Dixon 1988:132)

36. Au tadra-a a omu aa la'o mai

1SG dream-TR ART your PST go DIR

'I dreamt that you had come.'

According to Krupa (2005:513), who wrote, concerning the following example: "the deverbative is marked with te $i$ [that is, with the specific article + past tense marker], which seems to be statistically rare", the past tense marker is also licensed in nominalizations of Marquesan:

Marquesan (Krupa 2005:513) 
37. [Te i ite-tina na tunane tata eka te tihe te kui i una], SPEC PST see-NMLZ PAUC brother nearly reach SPEC come SPEC mother LOC top atahi kokoti na tunane te ouoho no Hina.

then cut PAUC brothers SPEC hair POSS Hina

'When the brothers saw that the mother had nearly reached the top, (then) they cut Hina's hair.'

\section{b) Perfective}

The perfective aspect is probably the aspect most often encountered inside of nominalized phrases in other languages.

In Cèmuhî, the perfective aspect can be inserted between the nominalizing prefix and the verb:

Cèmuhî (Rivierre, 1980:268)

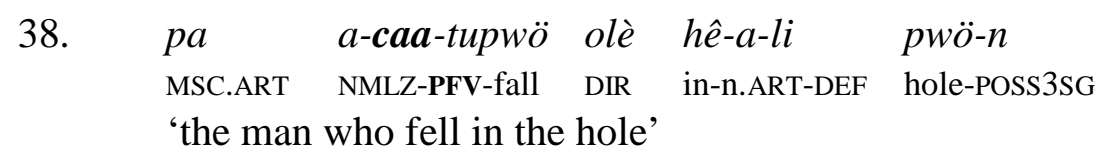

The perfective aspect is also found in nominalizations in Polynesian languages, such as Tokelauan ${ }^{3}$ or in East Uvean:

Tokelauan (Matagi Tokelau, 1990:62 in Vonen 1993)

39. Na teteki lele kimatou [...] i te kua tatago mai ki ei. PST be.surprised(PL) very 1PL.EXCL OBL SPEC PFV touch(PL) DIR OBL ANAPH

'We were very surprised at their touching them.'

East Uvean

40. Kua vaha'a lua nei te kua fakahifoo te 'aliki hau o Alo, PFV week two now SPEC PFV put.down POSS SPEC chief king POSS Alo

e tana fämili.

ERG his family

'It is now two weeks since the king of Alo was overthrown by his family.' (lit. the dismissal of the king of Alo by his family was two weeks ago)

In Samoan, the perfective aspect is attested at least in nominalized phrases introduced by the specific article:

Samoan (Mosel \& Hovdhaugen 1992:644)

41. ...le fana e sasa ai le tamaitaie le ua molia. SPEC gun NPST hit ANAPH SPEC lady ERG SPEC PFV sue.TR

'...the gun with which the accused hit the lady.'

\section{c) Perfect}

The perfect is found at least in one Toqabaqita example ${ }^{4}$ : Toqabaqita (Lichtenberk 2008:567)

42. Ta wane $\mathrm{ka}$ loloqe mae-laa naqa,...

one man 3SG:SEQ pretend die-NMLZ PERF

'One of the men pretended to have died...'

\footnotetext{
3 Hovdhaugen et al, however, observe that all words of the verb phrase except the tense words are retained when it is transformed into a noun phrase (1989:101) and tense, in this book, also includes aspects such as perfective kua, or progressive koi.

4 According to Lichtenberk, there are no other examples of nominalizations in Toqabaqita occurring with tense/aspect markers. There is, however, reduplication of nominalizations to express continuativity or iterativity, as in fii-fita-laa /RED-run-NMLZ/ 'the runnings' (Lichtenberk 2008: 441, ex. 9-71).
} 


\section{d) Imperfective}

The imperfective aspect is found in Tahitian nominalizations, where the article te combines with the imperfective $e$ in a nominalized clause, as in example (13), repeated below:

Tahitian (Lazard \& Peltzer 2000:83)

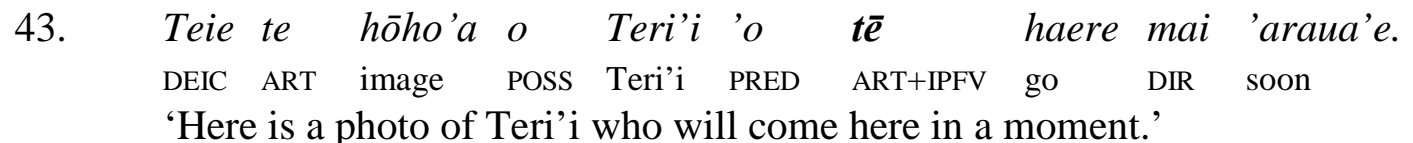

The same is true of Samoan, where we find the 'general tense-aspect-mood particle' in a nominalized phrase as a benefactive argument introduced by the preposition ma: Samoan (Mosel \& Hovdhaugen 1992:644)

44. ...e pei o le ave o sina masima ma le e sue masima mai NPST be.like PRED SPEC give POSS ART salt BEN SPEC IPFV look.for salt DIR '....as, for instance, giving some salt to someone who is looking for salt...' (Lit. it is like the giving of some salt to the one looking for salt...)

These constructions are indeed quite frequent in conversational speeches, as is also the case in the following Xârâcùù example.

Xârâcùù

45. Kèè-nä-xwi rè wîrî mwâ mê kèè-nä-néxä rè wîrî kèè-xwi rè NMLZ-IPFV-make POSS 2PL house and NMLZ-IPFV-know POSS 2PL NMLZ-make POSS mwâ mè nä xùpuurè mè wîrî nä bwèrè dèèri rè ngê chaa daa töxûtèpe! house FUT IPFV origin that 2PL IPFV some people IPFV during one day on custom 'The construction of houses, to know how to build houses, will make you men of custom!'

\section{e) Progressive}

The progressive aspect occurs inter alia in East Uvean and in East Futunan nominalizations: East Futunan

46. E 'ita a Soane $i$ le koi nonofo a Malia mo lona tinana. IPFV be.angry ABS Soane OBL SPEC PROG RED..stay POSS Malia and her mother 'Soane is angry because Malia is still with her mother.'(Lit. Soane is angry at the still staying of Malia and her mother)

The past progressive marker is also possible in Xârâcùù, as shown below:

Xârâcùù

47. Mââitaa kèè-nää-fè-cha rè ri, ri nää tî rè mwâ. before NMLZ-PROG.PST-go-cut POSS 3PL 3PL PROG.PST measure IPFV house 'Before their going to cut the wood, they were measuring the house.'

48. ù-nää-kwé rè ri NMLZ-PROG.PST-dance POSS 3PL

'the place where they were dancing'

\section{f) Immediate}

The immediate aspect occurs in nominalizations at least in East Uvean: East Uvean

49. 'E au nofo pē anai $i$ heñ̄ oa'uki te hoki liliu mai a koulua. NPST 1SG stay RESTR FUT OBL ici up.to SPEC IMM return DIR POSS 2DU 'I will stay here until your imminent coming back.' 
The preceding examples have shown that (nearly) all tense-aspect categories are also found in nominalizations of some Oceanic languages, a rare and thus remarkable phenomenon in the world's languages.

\subsection{Constraints}

The tense-aspect markers listed above are not found in nominalizations of all Oceanic languages, however. There are constraints depending on a variety of factors.

Let us now turn to these different constraints imposed on the selection of tense-aspect markers in nominalized phrases or clauses and the semantic and/or syntactic properties they might be due to.

One possible, very general hypothesis is that the occurrence of tense-aspect markers is linked to a weak distinction between nouns and verbs. This, however, is clearly not the case, since in New Caledonian languages, where nouns and verbs are clearly distinguished, there are fewer restrictions for tense-aspect in nominalized clauses than in some Polynesian languages, where tense-aspect markers are not allowed at all. I also examined the meaning of the nominalized verbs occurring with tense-aspect, but I found no clear evidence for restrictions. What I found was that different types of constraints exist, depending on the tense-aspect marker itself (§3.2.1.), or, in some Polynesian languages, either on the presence of a nominalizing suffix on the verb (§3.2.2.) or on the choice of the article (§3.2.3.). None of these constraints, however, seem to be linked to the type of the argument structure (§3.2.4.)

\subsubsection{Constraints on the selection of individual tense-aspect markers}

As far as the type of tense-aspect markers licensed in or excluded from nominalized constructions is concerned, I did not find any clear systematicity across Oceanic languages. In some Polynesian languages, tense markers cannot occur inside the nominalized phrases or clauses. The same restrictions exist for nominal clauses, in which the tense marker is external to the nominal clauses:

East Uvean

50a. 'E ko te tagata fai'ako, koe?(50b) ne'e ko te tagata fai'ako, koe? NPST PRED SPEC man teach 2SG PST PRED SPEC man teach 2SG 'You are a teacher, you?" You have been a teacher, you?'

In Xârâcùù, it is just the opposite: the perfective marker is not allowed inside the nominalized phrases, whatever the verb valency, while the past marker, as we have seen (33-35) is unproblematic. The perfective marker wâ must occur before the nominalized construction. Xârâcùù

51. Wâ kèè-coa rè Anik ku.

PFV NMLZ-peel POSS Anik yam

'It is now the way Anik peels yams.'

In Fagauvea, as in the other Polynesian Outliers, no tense-aspect markers are licensed in nominalized phrases; Fagauvea, however, allows hano (grammaticalised from the verb 'to go') which conveys a modal value (obligative or irrealis mood), as in (52b.):

Fagauvea (Uvea, Loyalty islands, Polynesian Outlier) (A. Djoupa, p.c.)

52a. $\mathrm{Gu}$ de fetali gi de fale-tau ainei de vaka.

1SG IPFV wait OBL SPEC NMLZ-land soon SPEC boat

'I am waiting for the landing of the boat in a few moments.'

52b. $\mathrm{Gu}$ de fetali gi de fale-hano-tau ainei de vaka. 1SG IPFV wait OBL SPEC NMLZ-IRR-land soon SPEC boat 'I am waiting for the boat which should be landing in a few moments.' 
In South Efate, a derived noun, nominalized by the article $n a$ - and the nominalizing suffix -wen may include the 'be' copula in its irrealis form ( $f i)$ :

South Efate (Vanuatu) (Thieberger 2006:137)

$\begin{array}{lll}\text { 53. Na-soklep-wen } & \text { gar } & \text { i-top. } \\ \text { ART-be:IR-rich-NMLZ } & \text { 3PL.POSS } & \text { 3sG.RS=much } \\ \text { 'Their wealth }\end{array}$

It seems that this is the only possible tense-aspect-mood occurrence in South Efate nominalized constructions.

\subsubsection{The role of affixes}

Severe restrictions seem to occur in most Polynesian languages when the nominalization process includes a nominalizing affix. The crucial point here seems to be whether the nominalizing prefix only has a nominalizing function, or whether it also conveys aspectual values, and consequently prevents verbal tense-aspect expressions. Thus in Tahitian, the presence of the nominalizing suffix on the verb prevents the occurrence of the aspect marker. The nominalizing suffix itself conveys a meaning (perfective/resultative) similar to the aspect marker.

Tahitian (Poeura Tetoe, p.c.)

54a. 'Ua māere au i tā'oe pahono-ra'a.

PFV be.surprised 1SG OBJ your answer-NMLZ

'I am surprised by your answer.'

54b. 'Ua māere au i tā'oe i pahono(*-ra'a).

PFV be.surprised 1SG OBJ your PFV answer

I am surprised by your answer.

In East Futunan, tense-aspect markers are not found when the verb is suffixed by $-g \bar{a}$ : the patient/absolutive argument is just juxtaposed to the nominalized verb, and not expressed as a possessor as is the case without the suffix. As in Tahitian, the nominalizing suffix is sufficient by itself to express a perfective aspectual meaning.

East Futunan

55. Na fai le faka-nofo-gā sau fulumalie

PST happen SPEC CAUS-sit-NMLZ king beautiful

'The beautiful investiture of the king has happened.'

The same situation is found in Rennell and Bellona verbal clauses, where the suffix 'aya is sufficient to convey a past or perfective meaning, as shown in (56) and (57).

Rennell and Bellona (Elbert \& Schütz1988:149)

56. te māsaki-‘anga a Moa

SPEC sick-NMLZ POSS Moa

'Moa’s (past) sickness.'

57. Te tā-‘anga e Moa toku baka.

SPEC build-NMLZ AGT Moa my canoe

'Moa made my canoe.' (Lit. the has made by Moa my canoe)

In (57), as it is the case in East Futunan example (55), the absolutive argument of the transitive verb is not expressed as a possessor. With transitive verbs, the suffix both prevents the occurrence of tense-aspect markers, and the expression of the patient in a possessive phrase. In Rapanui also, no tense-aspect is admissible in combination with the -Vya suffix, which is described as imperfective (“as yet unrealized”) in Du Feu 1996: 178-179).

Rapanui (Du Feu 1996:118) 
58. Ko tikea'a e au te tetere-ina o raua.

PFV see.RES AGT 1SG SPEC RED.run-NMLZ POSS 3PL

'I saw them all running away.'

In Nêlêmwa, the derivation with the shâ- prefix conveys a stative/resultative meaning (59) whereas the $-a$ nominal determiner suffixed to the nominalized verb conveys a prospective or generic value (60).

Nêlêmwa (Extreme-North of the Mainland, New Caledonia) (Bril 2002:77-80)

59

$\begin{array}{lll}\text { shâ-tilu } & i & n a . \\ \text { NMLZ harvest } & \text { POSs } & \text { 1sG } \\ \text { 'my harvest.' } & & \end{array}$

60.
Hla vhajamalî u-khabe-a mwa eli.
3PL discuss NMLZ-build-DET house DEIC
'They are talking about the construction of this house.' (prospective)

These examples show that whereas in some languages such as Xârâcùù, the nominalizing prefix only has a nominalizing function, nominalizing affixes in other languages also convey aspectual values, and consequently prevent verbal tense-aspect expressions.

In Tokelauan, however, the nominalizing suffix AND an aspect marker may co-occur, as shown in (61).

Tokelauan (Hooper 1996:228, from Vonen 1988)

61. Ko te $\boldsymbol{k a}$ fano-ga o te tino, na tāofi ai e tētahi tino. PRED SPEC IMM gO-NMLZ POSS SPEC person PST stop ANAPH ERG another person 'On the occasion of the person being about to go, he was held by another person.'

Once more, we can observe how difficult it is to make reliable generalizations about the occurrence of tense-aspect markers in nominalized constructions.

\subsubsection{Constraints imposed by articles}

Further constraints concern the compatibility of nominal determiners as signals of the nominalization and tense-aspect markers. In most Polynesian languages, only the specific article may nominalize a verb phrase, as is the case with le in East Futunan $(P P N * t e)$. As already mentioned, the same restrictions occur in Vaeakau-Taumako (cf. Naess \& Hovdhaugen 2011:57), and in Tahitian (Vernaudon \& Rigo 2004).

In East Futunan or in East Uvean, languages, where aspect markers are allowed in nominalized clauses, other articles than the specific one may indeed nominalize verbal phrases; but then, the nominalized phrase loses its referential quality; it denotes a type of entity, and cannot be determined anymore by any aspect marker, or by any directional adverb. These are then pure cases of lexical nominalizations:

East Uvean

62. Ne'e mole ina kai te mo'i pane $i$ hana fia kai PST NEG 3SG eat SPEC CLAS bread OBL NSPEC+POSS feel.like eat

kae ne'e ina kai $i$ te lahi o te me'akai. but PST 3SG eat OBL SPEC big POSS SPEC food

'He didn't eat the piece of bread because he was hungry, he ate it because there were plenty to eat!' (*i hana kua fia kai)

East Futunan 
63. Na votea ia kiā Petelo i ni ga'oi loi na fakapapau kiate ia. PST vote ABS 3SG OBL Petelo OBL NSPEC.PL work lie PST promise OBL 3SG 'He voted for Petelo because of the false promises of work that had been given to him'. (*i ni kua ga'oi loi)

\subsubsection{The role of argument structure}

In my data, I found no differences in the licensing of tense-aspect markers depending on the argument structure of the languages, in contrast to Koptjevskaja-Tamm (1993:160) statement that "very few verbal features are retained in nominalisations of the ERG-POSS type". In the 25 languages of her sample, only one language (Hixkaryana) has tense, and Modern Hebrew and Māori have negation (in Māori, of the nominal type, that is, English no). Among the languages of the POSS-ACC type (25 languages), Māori and Modern Hebrew are again listed as having negation, plus Egyptian, English, Swahili and Turkish; tense is found in four languages (Evenki, Mongolian, Turkish and Tuva), and aspect in English. Among the 17 sentential-type languages ${ }^{5}$, 8 have distinct tense-aspect markers in clauses with action nominalizations (Koptjevskaja-Tamm 1993:255).

\section{Negation}

As is the case with tense-aspect markers, the admissibility of the negative marker inside the nominalized phrase is variable in Oceanic languages. In some languages the usual verbal negators are admissible, in others only the nominal negators are possible in nominalizations (cf. English not vs. no) and in still others negation seems to be totally excluded from nominalizations.

\subsection{Negative markers are allowed. ${ }^{6}$}

Negative particles may occur in nominalized constructions in a number of languages including Tuvaluan (Besnier 2000: 510) and East Uvean in combination with the progressive marker in (64):

East Uvean

64. Ko te mole kei tō o te kava e ia. PRED SPEC NEG PROG plant POSS SPEC kava ERG 3SG

'(It is a fact) he doesn't grow kava anymore.' (Lit. It is the not still growing of the kava by him)

This is also possible in Tokelauan with $h \bar{e}$ 'not'as negative marker, or with $h \bar{e} k i$ 'not yet'. Tokelauan (Hooper 1996:228, from Vonen 1976)

$\begin{array}{lllllllllll}\text { 65. I } & \text { te } & \boldsymbol{h} \overline{\boldsymbol{e}} \boldsymbol{k} \boldsymbol{i} & \text { maua-ga } & \text { o } & \text { ia } & \text { oi } & \text { toe } & \text { liliu ai } & \text { kilāua } \\ \text { OBL } & \text { SPEC NEG } & \text { obtain-NMLZ } & \text { POSS } & \text { 3SG } & \text { then again } & \text { return ANAPH } & \text { 3DU } \\ k i & \text { Ieluhalema. } & & & & & & & & \\ \text { OBL } & \text { Ieluhalema } & & & & & & & \end{array}$

'On the occasion of [their] failing to find him they went back to Jerusalem.'

Negative markers are also admissible in nominalizations of Xârâcùù:

5 Sentential type: all the arguments in Action Nominal Constructions retain their sentential dependingmarking. (id.:61).

${ }^{6}$ In other Austronesian but non-Oceanic languages, negative markers may also be part of nominalized constructions: Kaufman (2011:743) gives Tagalog examples with what he calls "gerunds", that is, our action nominalizations, which include a negative marker:

ang hindi mo pag-pasok

NOM NEG 2SG.POSS GER-enter

'your not entering' 
Xârâcùù

66. ù-kaxê röö, kèè-sii-da-xëtë-röö mê mwîn kèè-fiö röö, NMLZ-big POSS+2SG NMLZ-NEG-eat-hard-POSS+2sG and big NMLZ-lazy POSS+2sG

è xwipuurè nämè wâ-rö kwèti.

3sG to.cause that self-2sG be.tired

'Your being big is not due to your eating too much and to your laziness, it is due to your tiredness.'

In Fagauvea, too, the inclusion of the negative marker in the nominalized phrase is possible and frequent.

Fagauvea (A. Djoupa; p.c.)

67. Goi $i$ de moonii-ina (dona) fale-he-numai anaafi a Sinoki. PROG 3SG NPST be.angry-TR his NMLZ-NEG-come yesterday PERS Sinoki 'She keeps being angry [because] Sinoki didn't come yesterday.'

In Samoan, according to Mosel \& Hovdhaugen (1992:531) "the nucleus of nominalized verbal clauses is formed by verbs (which can be negated by $l \bar{e}$ 'not' and modified by prenuclear and post-nuclear adverbs), whereas the nucleus of other noun phrases does not combine with negative particles or adverbs".

Samoan (Mosel \& Hovdhaugen 1992:531)

68. Sa ou nofo ma le le fiafia...

PST 1SG stay with ART NEG be.happy

'I stayed there and was unhappy...' (Lit. I stayed there with the not being happy)

\subsection{Nominal negation only}

In Kokota (Palmer 2009: 307ff.) negation "is expressed in two ways: by the use of the negative particle $t i$ and by a subordinating construction involving the negative existential verb teo 'not exist'. The latter is by far the more frequent strategy but the particle $t i$ is the only means of marking negation in nominalized clauses, in manner deixis constructions ('be thus') and in nonverbal predications". The negative marker $t i$ is found in example (69):

Kokota (Santa Isabel, Solomon islands) (Palmer 2009:308)

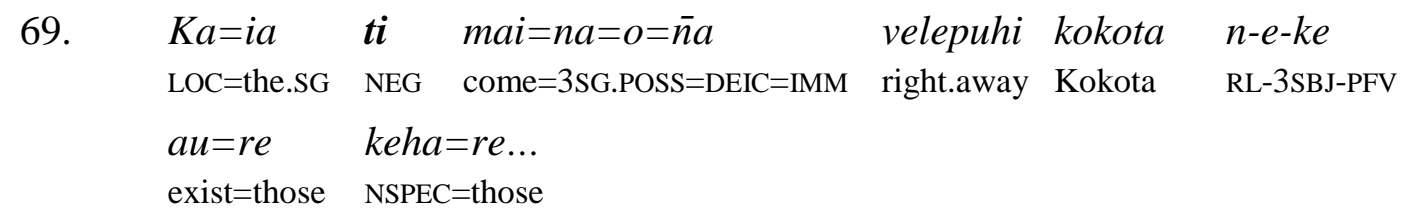

'At that non-coming of Christianity [i.e., When Christianity had not yet come] some lived at Kokota...'

\subsection{Negative markers are not allowed}

Lichtenberk (2011:706) notes for Toqabaqita that “...while nominalizations can occur with certain particles that occur with verbs, they do not express the future-non-future tense distinction and cannot be negated".

For Iaai (Uvea, Loyalty islands), Ozanne-Rivierre gives examples of typical deprecating exclamative clauses in which the standard negative marker caa combines with the nominalized verb, but occurs before the nominalizing prefix.

Iaai (Uvea, Loyalty islands) (Ozanne-Rivierre 1984:36)

70a. Caa û-nââk-iny miitr!

NEG NMLZ-tough-SUF meat

'Isn't this meat tough!' (Lit. not the toughness of the meat) 
This judgement is not shared by the informants I consulted, who also find the word order in (70b) perfectly admissible:

$70 \mathrm{~b}$.

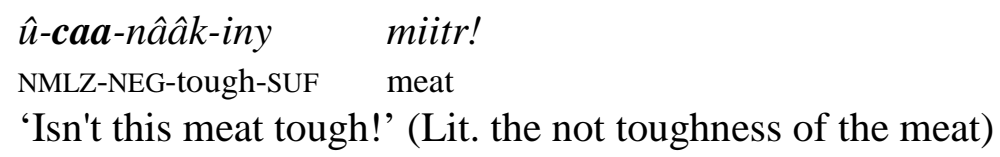

\section{Subject plural agreement}

In Polynesian languages, there do not seem to be restrictions as far as subject-plural agreement is concerned. Reduplication, as a marker of subject plural agreement, is maintained in nominalizations, as we saw in East Futunan example (46), as well as in Rapanui (71) or East Uvean (72) below:

Rapanui (Du Feu 1996:118)

71. Ko tikea'a e au te tetere-ina o raua.

PFV see.RES AGT 1SG SPEC RED.run-NMLZ POSS 3PL

I saw them all running away.

In East Uvean as well, the nominalized verb keeps its suppletive plural form. East Uvean

72. Pea matou olo ai leva, te olo atu a mātou o tau atu. and 1PL.EXCL go(PL) ANAPH EMPH SPEC go(PL) DIR POSS 1PL.EXCL COMP land DIR 'We went off, our going off [was] in order to land over there.'

\section{Compatibility with adverbs}

Adverbs, directionals in particular, are frequently found in nominalized phrases (see examples 13, 22, 36, 39, 44, 49, 70 above; strikingly, in most of these examples, it is the ventive 'towards the speaker' directional which occurs). Toqabaqita very rarely accepts tense-aspect markers in nominalized constructions (only one occurrence was found in Lichtenberk's 2008 grammar), whereas directionals may occur ${ }^{7}$ :

Toqabaqita (Lichtenberk 2008:439)

73. Maqasi nau qana oli-la-ku mai.

wait.for 1SG PREP return-NMLZ-1SG DIR

'Wait for me to come back.' (Lit. Wait for me until my returning here)

Besides directionals, other types of adverbs may be kept in the nominalized phrase, such as xaari 'alone' in the following Xârâgurè example, occurring in a verbal phrase (74a) as well as in the nominalized counterpart (74b):

Xârâgurè (Mainland of New Caledonia)

74a. Gö wakè xaari wâ loto rè nâ.

1SG work alone OBL car POSS 1SG

'I am fixing my car by myself.'

74b. Gö tômwâ kèè-wakè xaari rè wâ loto rè nâ.

1SG know NMLZ-work alone POSS OBL car POSS 1SG

'I know how to fix my car by myself.'

Nominalized exclamative clauses often contain focus particles, degree adverbs or emphatic markers, such as Māori hoki, East Uvean leva, as shown by the examples below.

Māori (Bauer, 1997: 526)

\footnotetext{
${ }^{7}$ Directionals can occur with verbs and in nominalizations, but not with 'true' nouns (p. 439).
} 
75. Te makariri hoki o te wai!

SPEC cold EMPH POSS SPEC water

'How cold the water is!'

East Uvean

76. 'I poto leva o Soane!

OBL intelligence EMPH POSS Soane

'How intelligent Soane is!' (Lit. at intelligence of Soane)

In Xârâcùù, the focus particles may determine a nominalized phrase, as is the case in the following exclamative clause:

Xârâcùù

77. Dö kèè-nââ-mètusé rè nâ!

really NMLZ-feel.like-sleep POSS 1SG

'How sleepy I feel!' (Lit. my very feeling like sleeping)

\section{Arguments in nominalized clauses}

Whereas I found no differences in the admissibility of tense-aspect markers in nominalized verb phrases depending on the argument structure of the languages, there are important differences depending on the marking of arguments in the relevant language.

Comrie (1976) noted that among verbal arguments, the subject is the first candidate to receive possessive encoding in nominalized phrases. This is true for accusative languages such as Xârâcùù. In ergative languages, it is the absolutive argument which is coded as possessor ${ }^{8}$, the ergative argument remaining in the ergative case. The expression of arguments in nominalized phrases is thus linked to the encoding of grammatical relations and to the type of valency found in the languages. In the Polynesian ergative languages, the agent arguments in nominalized phrases are expressed either as possessor when the construction is intransitive, or retain their ergative marker when the construction is transitive. In accusative languages such as Xârâcùù, by contrast, the agent is always downgraded as possessor, no matter what the nominalized verb's original valency is and so is the patient in intransitive construction; in transitive construction, however, the patient (former object) remains unmarked.

\subsection{Ergative languages}

In ergative Polynesian languages, when only one argument is expressed, it occurs as a possessor, introduced either by the alienable possessive marker $(a)$ if it refers to an agent (78a), or by the inalienable one (o) if it refers to a patient (78b):

East Uvean

78a. Pea faifai te tau tu'u a Vaka'ana ki te fono. and go.on SPÉc often stand POSS Vaka'ana OBL SPÉC council 'Vaka'ana was still often going to the council.'

78b. Pea ne'e ko te tu'u 'âfea mai o te kolo 'aenī. and PST PRED SPEC stand once DIR. POSS SPEC village DEIC

'And once it was the custom of this village"'

\footnotetext{
8 There is, however, an exception: when the transitive verb is nominalized by a suffix (§ 3.2.2.), the patient cannot be expressed as a possessive phrase; it remains unmarked, as it is the case in an accusative language such as Xârâcùù.
} 
In nominalized transitive constructions, arguments referring to agents remain in the ergative case, but there is no absolutive case marking in nominalized phrases or clauses, the original absolutive argument (referring to the patient) being marked as an inalienable possessor: East Uvean

79. 'E sio'i e Malia te kai o te mo'i mei e Sosefo. NPST look.at ERG Malia SPEC eat POSS SPEC CLF breadfruit ERG Sosefo 'Malia is looking at Sosefo eating a piece of breadfruit.' (Lit. Malia is looking at the eating of a piece of breadfruit by Sosefo)

\subsection{Accusative languages}

In accusative languages such as Xârâcùù, by contrast, the agent of a transitive verb is downgraded to the status of possessor, while the patient is simply juxtaposed to it, without any marking. This is the case irrespective of the categorical status of object or subject. In the following Xârâcùù example, the second nominalized phrase (kèè-sakwîn...) includes a possessive noun phrase referring to the agent (röö), followed by a free pronoun referring to the patient $(g u)$.

Xârâcùù

80. Nâ chéxwaé kèè-xwi rè wâ du rè kèè-sakwîn na röö gu. 1SG explain NMLZ-do POSS about price POSS NMLZ-take.care PST POSS+2SG 1SG.INDEP 'I am going to explain what to do, as a reward of your taking care of me.'

In example (79), with a nominal object: full sentence

81. ù-fa-céé na rè acaa kwâ NMLZ-CAUS-land PST POSS fisherman boat 'place where the fisherman made the boat land' (Moyse-Faurie 1995:57)

When there is only one argument in the nominalized clause, it is always expressed as a possessor, regardless of whether it refers to an agent (82a) or a patient (82b):

82a. ù-sëi rè wîrî

NMLZ-shovel POSS 2PL

'the place where you are shoveling'

82b. ù-sëi rè nâwâ

NMLZ-shovel POss sand

'the place of sand shoveling'

And when both arguments are expressed, it is the agent which is marked as possessor, while the patient (nâwâ in (82c)) is relegated to the periphery without any specific marking:

82c. ù-sëi rè wîrî nâwâ

NMLZ-shovel POSS 2PL sand

'the place where you are shoveling sand'

\subsection{Other cases}

In Nêlêmwa, the patient retains its verbal marking and position (object pronominal -yo suffixed to the verb), whereas the agent (na) is expressed as the possessor, in second position. Nêlêmwa (Bril 2002:79)

83. Hna-kûûlî-a u-axi-yo i na

NMLZ-finish.TR-POSS NMLZ-see.TR-2SG POSS 1SG

It is the last time I saw you. (Lit. the end of my vision of you)

In Fagauvea, different argument markings are possible. 
If the nominalized verb is intransitive, the argument is marked as the possessor, whether it refers to an agent or to a patient.

Fagauvea (A. Djoupa, p.c.)

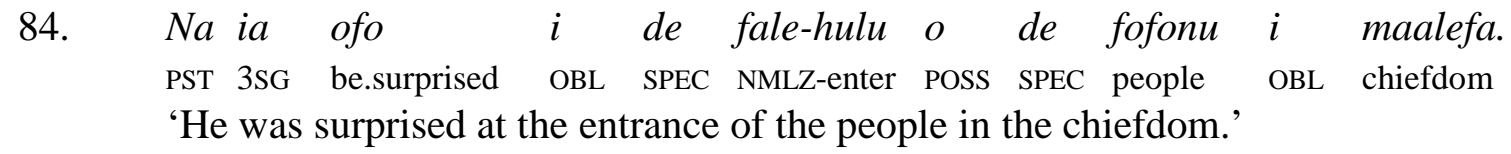

If the nominalized verb is transitive, the object, referring to the patient, keeps its verbal position and marking, regardless of whether the agent is expressed or not.

85. Gu de sakilia $e$ hele mo de tuakia mala fai atu.

1SG IPFV search.for NSPEC knife COMP SPEC eviscerate PL CLF bonite

'I am looking for a knife in order to eviscerate the bonites.'

If the agent is expressed, it follows a nominal object (86), or it is expressed as a pronominal possessor (87):

86. Na vave de fale-faua domadou fale a tāngata.

'The men have quickly built our house.' (Lit. has been quick the building our house the men)

87. Na ia kitea dolea fale-sunua dou vaka.

PST 3SG see.TR their NMLz-burn.TR your boat

'He has seen the way they burned your boat.' (Lit. their burning your boat)

\section{Conclusions}

Nominalization is a very productive strategy in Oceanic languages, with a large spectrum of possible uses. Besides the usual functions linked to nominalizations as a result of the syntactic position they fill (arguments, clausal complements), we have seen that nominalized exclamative clauses may be considered as the prototypical expression of exclamation in many Oceanic languages. While adverbs, directionals and emphatic particles are most often kept in nominalized clauses, there are several types of constraints concerning the expression of tenseaspect or negation markers, even though they do occur quite often in nominalized constructions.

In the following final section, I will try to explain the constraints observed, either in terms of historical processes of change or in terms of typological generalizations.

\subsection{Diachronic considerations}

Constraints which are linked to the expression of a nominalizing affix may have a historical explanation. Indeed, in some Austronesian languages (such as Cebuano, cf. Himmelmann 2005:126) focus/voice markers also often convey tense-aspect-mood information, and as suggested by Starosta, Pawley and Reid (1982), some of these voice markers are derived from affixal nominalizers ${ }^{9}$, as in Saisiyat:

Nominalizer $\rightarrow$ focus/voice marker $\rightarrow$ resultative/perfective/anterior

So we could suggest the following evolutionary scenario:

Some languages retained the old aspectual value of the nominalizers and, as a consequence, do not allow tense-aspect markers in their nominalized constructions.

\footnotetext{
9 This evolution is attested elsewhere in the world, as for example in Tibeto-Burman languages or in Mandarin dialects. In a recent communication, Coupe (2012) addressed the following question: "Is it mere coincidence that two nominalizers are isomorphic with two of the tense markers of Mongsen Ao, or do nominalizers provide a diachronic source for yet another extended function of nominalization in this language, namely the tense/mood categories?” (Coupe 2012).
} 
Other languages lost the aspectual value of their nominalizers, or even changed the nominalizing suffixes into new prefixes. Later on, however, whenever aspect or tense had to be expressed in their nominalized constructions, they simply retained what they had at hand in verbal clauses, that is, verbal tense-aspect markers! These two putative developments can be summarized by the following diagram:

$\Rightarrow$ Retention of the old aspectual value of the nominalizers $>$ no tense-aspect markers in the nominalized constructions.

$\Rightarrow$ Loss of the aspectual value of the nominalizers $>$ insertion of verbal tense-aspect markers in nominalized constructions.

\subsection{Typological implicative hierarchy}

The very last point I would like to make is a typological one: Is there any ordering of the features that are acquired or lost during nominalization? I tried to compare my data with some theories establishing a cline of deverbalization / nominalization processes.

My data can be summarized in the following table:

$$
\text { more verbal features }
$$

tense-aspect

article

specific

non-specific

prefix

affix

suffix

agent as possessor

more nominal features

$\pm$

$\pm$

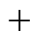

$\pm$

$+$

$+$

The occurrence of a suffix or of the non-specific article and the expression of the agent as a possessor clearly increase the nominal character. Some features, such as the occurrence of a tense-aspect marker, of a specific article or of a nominalizing prefix, by contrast, induce neither a more verbal nor more nominal character. Arguments in nominalized clauses manifest a variable ability to be expressed as possessors depending on the verb valency. If the nominalized verb is intransitive, most languages allow a possessive expression of the argument. When the verb is transitive, by contrast, there is more variability: it may depend on the way grammatical relations are marked in the language, on the syntactic category of the arguments or on the type of the nominalizing strategy.

In the typological literature on nominalization the following implicational hierarchies have been proposed for the constraints observed.

(i) Noonan (1985:57) gives the following implicational hierarchy on the basis of his data:

Subject agreement and Mood $>$ Tense $>$ Aspect $>$ Voice, Valency, Object agreement. This scale must be read as follows: the further to the left a category is on the scale, the less likely is it to be encoded on a nominalized complement. 
As we saw in $\S 5$, subject verbal agreement is maintained in Polynesian nominalized phrases. On the other hand, tense is not encoded inside nominalized phrases in these languages, even if all the other categories are.

(ii) Croft (1991:83) proposes the following "Deverbalization Scale":

Finite TAM retained $>$ S-marking retained $>$ O-marking retained [> means 'implies'] In most of the languages of our data, however, the retention of tense/aspect markers in nominalizations is stronger than the retention of case markers. Nêlêmwa on the opposite, reflects the deverbalization scale proposed by Croft: nominalizations loose the tense-aspectmood categories, but retain valency markers.

(iii) Finally, Comrie \& Thompson (1985) note that aspect and voice may be retained in lexical nominalization, tense rarely, and mood and verbal agreement virtually never:

Illocutionary force $>$ mood $>$ tense $>$ aspect

As we have shown in this article, the occurrence of tense and aspect markers is attested not only in lexical nominalizations, but is also quite frequent, as far as Oceanic languages are concerned, in phrasal and clausal nominalizations, that is, at the syntactic and discourse level as well.

Thus, such implicational generalizations do not fully apply to all Oceanic languages. Moreover, as noted by Malchukov (2005), these generalizations are not always compatible with each other. Predictions such as the relative susceptibility of agreement and tense-aspectmood categories to get lost are constrained by a semantically (scope and relevance) based hierarchy of verbal categories. For example, "tense affects the meaning of the verb stem less directly than aspect does.” He suggests to base such predictions on a hierarchy of verbal categories as established in the functional- typological literature.

Finally, I found no instances of Malchukov's final step, that is, "full decategorization involving the loss of all verbal categories", in the Oceanic languages.

\section{Abbreviations}

ABS absolutive, AGT agent, ANAPH anaphoric, ART article, BEN benefactive, CAUS causative, CLF classifier, COLL collective article, COMP complementizer, DEIC deictic, DESID desiderative, DET determiner, DIR directional, DU dual, EMPH emphatic, ERG ergative, EXCL exclusive, FOC focus, FUT future, GER gerondive, IMM immediate, INDEP independent, INT intensifier, INTERJ interjection, IPFV imperfective, LOC locative, NEG negation, NMLZ nominalizer, NOM nominative, NPST non past, NSPEC non specific article, O object, OBJ object marker OBL oblique, PERS personal article, PFV perfective, PL plural, PN proper name, POSS possessive, PRED predicative, PREF prefix, PROG progressive, PROH prohibitive, PST past, RED reduplication, REL relative, RES resultative, RESTR restrictive, RL realis, RS realis subject, $S$ subject, SBJ subject marker, SEQ sequential, SG singular, SPEC specific article, SUF suffix, thatN that (nearby), thatNV that (not visible), TR transitive suffix, VOC vocative.

\section{References}

Bauer, Winifred, 1997. The Reed Reference Grammar of Māori, New Zealand, Reed. Besnier, Niko, 2000. Tuvaluan: A Polynesian Language of the Central Pacific. London: Routledge.

Bril Isabelle, 2002, Le nêlêmwa (Nouvelle-Calédonie). Analyse syntaxique et sémantique, Paris, Peeters, Langues et cultures du Pacifique 16.

Chung Sandra, 1973, The syntax of nominalizations in Polynesian, Oceanic Linguistics 12: 641-86.

Clark Ross, 1981, Inside \& outside Polynesian nominalizations, in Hollyman J. and Andrew Pawley (eds), Studies in Pacific Languages and Cultures in honour of Bruce Biggs, Auckland, Linguistic Society of New Zealand, 65-81. 
Comrie, Bernard, 1976. The syntax of action nominals: a cross-linguistic study, Lingua 40, 177-201.

Comrie, Bernard and Sandra Thompson, 2007 [1985], Lexical nominalizations. In Shopen, Timothy (ed.). Language Typology and Syntactic Description, vol. 3. Grammatical Categories and the Lexicon, Cambridge, Cambridge University Press, 334-381.

Coupe, Alexander R., 2012. Communication on "Polyfunctional nominalizations in TibetoBirman: trajectories of grammaticalization”, Paris, 6 juin 2012.

Croft, William, 1991, Syntactic categories and grammatical relations: The cognitive organization of information, Chicago, University of Chicago Press.

Dixon R.M.W., 1988, A Grammar of Boumaa Fijian, Chicago-London, The University of Chicago Press.

Du Feu, Veronica, 1996. Rapanui, London / New York, Routledge.

Elbert, Samuel H. and Samuel Schütz, 1988. Echo of a Culture: A Grammar of Rennell and Bellona, University of Hawai'i Press, Oceanic Linguistics Special Publications 22.

Himmelmann, Nikolaus P., 2005. The Austronesian languages of Asia and Madagascar: Typological Characteristics. In Alexander Adelaar \& Nikolaus P. Himmelmann (eds.), The Austronesian Languages of Asia and Madagascar, London/New York, Routledge, 110-181.

Hovdhaugen, Even, Ingjerd Hoëm, Consulata Mahina Iosefo and Arnfinn Muruvik Vonen, 1989, A Handbook of the Tokelau Language, Oslo, The Institute for Comparative Research in Human Culture, Series B, No. 77.

Hyslop Catriona, 2001, The Lolovoli Dialect of the North-East Ambae Language, Vanuatu, Pacific Linguistics, Canberra, 515.

Hooper R., 1996, Type and instance nominalisations in Tokelauan, in Lynch, J. \& Fa'afo Pat (eds), Oceanic studies: proceedings of the First International Conference on Oceanic Linguistics, Pacific Linguistics C-133, 223-241.

Kaufman, Daniel, 2011. Exclamatives and temporal nominalizations in Austronesian. In Yap, Foong Ha, Karen Grunow-Hårsta and Janick WSrona (eds.), Nominalization in Asian Languages: Diachronic and typological perspectives, Philadelphia-Amsterdam, John Benjamins Publishing Company, 721-753

Koptjevskaja-Tamm M., 1993, Nominalizations, London and New York, Routledge, Theoritical Linguistics.

Krupa, Viktor, 2005. Syntax of Verbal Nouns in Marquesan, Oceanic Linguistics 44:2.

Lazard, Gilbert and Louise Peltzer, 2000. Structure de la langue tahitienne. Paris, Louvain, Peeters, Langues et Cultures du Pacifique 15

Lichtenberk, Frantisek, 2008, A grammar of Toqabaqita. Berlin and New York: Mouton de Gruyter.

— 2011. Nominalizations in Toqabaqita and closely related languages, in Yap, Foong Ha, Karen Grunow-Hårsta and Janick Wrona (eds.), Nominalization in Asian Languages: Diachronic and typological perspectives, 685-720.

Malchukov, Andrej, 2005. Remarks on deverbalization, Sprachtypologie und Universalienforschung 58, 97-110.

Mosel, Ulrike and Even Hovdhaugen, 1992. Samoan Reference Grammar, Oslo:Scandinavian University Press.

Moyse-Faurie C., 1995, Le xârâcùù, langue de Thio-Canala (Nouvelle-Calédonie). Éléments de syntaxe, Peeters-Selaf, Langues et Cultures du Pacifique 10.

- 1997, Grammaire du futunien, Nouméa, Centre de Documentation Pédagogique.

— 2005, Problèmes de catégorisation syntaxique dans les langues polynésiennes. In Lazard, G. et C. Moyse-Faurie (eds.) Linguistique typologique, Villeneuve d'Ascq: Presses universitaires du Septentrion, 161-192. 
— 2007, Les formes nominalisées du verbe dans quelques langues océaniennes, Faits de langues 30, 97-116.

- 2011. Nominalisation and exclamation in Oceanic languages, in Moyse-Faurie Claire and Joachim Sabel (eds), Topics in Oceanic Morphosyntax, Mouton de Gruyter, 135-160.

Næss, Åshild and Even Hovdhaugen, 2011. A Grammar of Vaeakau-Taumako, De GruyterMouton.

Noonan, Michael, 1985. Complementation. In Shopen, Timothy (ed.). Language Typology and Syntactic Description, vol. 2 Complex constructions. Cambridge, Cambridge University Press, 42-141.

- 1997. Versatile Nominalizations. In: Joan Bybee, John Haiman \& Sandra A. Thompson, Essays on Language Function and Language Type. Dedicated to T. Givón.

Amsterdam/Philadelphia: John Benjamins.

Ozanne-Rivierre, Françoise, 1984. Dictionnaire Iaai-Français (Ouvéa, Nouvelle-Calédonie), Paris, Peeters-Selaf, Langues et cultures du Pacifique 6.

Palmer, Bill, 2009. Kokota Grammar, Honolulu, University of Hawai'i Press, Oceanic Linguistics Special Publication 35.

Rivierre, Jean-Claude, 1980. La langue de Touho. Phonologie et grammaire du cèmuhî (Nouvelle-Calédonie), Paris, Selaf, Langues et civilisations à tradition orale 38.

Starosta, Stanley, Andrew Pawley and Lawr ence Reid, 1982. The evolution of focus in Austronesian. In Amran Halim, Lois Carrington and S.A. Wurm (eds), Papers from the Third International Conference on Austronesian Linguistics, vol. 2: Tracking the Travelers, Canberra, Pacific Linguistics, 145-170.

Tesnière, Lucien, 1959. Eléments de syntaxe structurale, Paris, éditions Klincksieck.

Thieberger, Nicholas, 2006. A Grammar of South Efate: An Oceanic Language of Vanuatu Oceanic Linguistics Special Publication, No. 33. Honolulu: University of Hawai'i Press.

Vernaudon J. et B. Rigo, 2004, De la translation substantivante à la quantification : vers une caractérisation sémantique de l'article te en tahitien, Bulletin de la Société de Linguistique de Paris XCIX, 457-480.

Vonen, Arnfinn Muruvik, 1993. Parts of speech and Linguistic Typology, University of Oslo.

Yap, Foong Ha and Stephen Matthews, 2008. The development of nominalizers in East Asian and Tibeto-Burman languages. In: Maria Jose López-Couso and Elena Seoane (eds.), in collaboration with Teresa Fanago. Rethinking Grammaticalization. New perspectives. Amsterdam/Philadelphia: John Benjamins, Typological Studies in Language 76: 309341. 